\title{
ORGANOCHLORINE PESTICIDE RESIDUES IN FISHES AND SHELL FISHES OF THE FLOOD PLAINS OF SONARGAON UPAZILA, BANGLADESH
}

\author{
Tonima Mustafa ${ }^{*}$, M. Niamul Naser, Gulshan Ara Latifa, \\ Mohammad Shoeb² and Nilufar Nahar ${ }^{2}$ \\ Department of Zoology, University of Dhaka, Dhaka-1000, Bangladesh
}

\begin{abstract}
The present study was carried out to assess the concentrations of organochlorine pesticide residues (DDTs; DDE, DDD, 2,4-DDT and 4,4-DDT) in natural fishes and prawn species during rainy-season (June-September, 2014) from flood plains of Sonargaon upazila, Bangladesh. The samples were extracted by Quick, Easy, Cheap, Effective, Rugged and Safe (GuEChERS) method and the extracts were cleaned-up by using $\mathrm{H}_{2} \mathrm{SO}_{4}$. Analysis of the samples for DDTs residues were carried out by using Gas Chromatograph with Electron Capture Detector (GC-ECD). Controlled fish sample (Cultured Rui fish) was used for the recovery experiments. Percent (\%) recovery was found to be in the range of $70 \%$ $113 \%$. The total DDTs contents of the head of different fish and prawn species ranged from $7.53 \pm 0.50 \mathrm{ng} / \mathrm{g}$ in Jatpunti ( $P$. sophore) to $39.20 \pm 3.76 \mathrm{ng} / \mathrm{g}$ in Bele (G. giuris) and of the body from $7.55 \pm 0.50 \mathrm{ng} / \mathrm{g}$ in Jatpunti (P. sophore) to 41.93 $\pm 3.63 \mathrm{ng} / \mathrm{g}$ in Chewa ( $P$. elongatus). While the total DDTs of the total body of seven fish and two prawn species ranged from $4.56 \mathrm{ng} / \mathrm{g}$ in Gurachingri (unidentified) to $37.15 \mathrm{ng} / \mathrm{g}$ in Chewa (P. elongatus). In the present study, $66.66 \%$ samples having value of (DDE + DDD)/DDT, lower than 0.5 ratios indicated the presence of new DDT inputs in the environments of Sonargaon area. The concentrations of total DDTs in all the samples were within the permissible MRL level i.e. for human consumption recommended by FAO-IAEA-WHO. As DDT is a long persistent and bioaccumulative substance in the environment, intake of significant amount of these toxic elements with our diet is a matter of great health concern.
\end{abstract}

Key words: OCPs, Gas chromatography, Fish and bioaccumulation

\section{INTRODUCTION}

Pesticide residue problem is an environmental hazard and becoming serious focus for human health. Organochlorine pesticides (OCPs) such as DDT and its metabolites are of great concern to the environmental scientists for several decades, due to their persistence, bioaccumulation, long-range transport, toxicity and adverse effects on environment and human health including reproduction and birth defects (Edwards 1987), immune system dysfunction,

*Author for correspondence: <add.-tonimamustafa@yahoo.com>. 1Department of Zoology, Jagannath University, Dhaka-1100, Bangladesh. ${ }^{2}$ Department of Chemistry, University of Dhaka, Dhaka-1000, Bangladesh.

(C) 2018 Zoological Society of Bangladesh DOI: https://doi.org/10.3329/bjz.v47i1.42029 
endocrine disruptions and cancer (Adeyemi et al. 2008). The use of organochlorine pesticides was started in the Bangladesh during the middle of 1950s for increase crop production (Rahman and Thapa 1999). After several decades of intensive use, these pesticides including DDT have been banned in Bangladesh since 1995 due to adverse effects on human health and environment (Matin et al. 1998).

Bangladesh is an agro-based riverine country enriched with vast fisheries resources. The intensive cultivation of the agriproducts depends upon the use of fertilizer, pesticides, insecticides, fungicides and herbicides. About $25 \%$ of these compounds pass to the nearby water-body and act as a pollutant sources for fish and other aquatic organisms. Moreover during rainy-season the agricultural low lands are overflowed by the flood water and also act as pollutant source. Fishes are used extensively for environmental monitoring because they uptake contaminants directly from water and food (Matin et al. 1998). Generally the ability of the fish to metabolize organochlorine is moderate; therefore, contaminants load in fish are well reflective of the state of pollution in surrounding environment (Matin et al. 1998).

Sonargaon upazila is famous for cultivation of different types of rice, jute, vegetables, banana, betel leaf, sugar cane etc. throughout the year (NDS 2013). Pesticides are used immensely due to lack of appropriate knowledge about their applications and untoward effects. During rainy-season, these agricultural low lands are under flood water and obvious to contaminate the aquatic environments. These contaminants can be potentially bioaccumulated in the fatty tissues of fish and biomagnified from lower trophic level to the higher trophic levels through food chain.

In spite of the previous intensive use and recent illegal use of DDT in the country, little or no monitoring of their levels has been carried out. However, a recent study by Nahar et al. (2008) and Hossain et al. (2016) identified DDT in fishes from different region of the country. In view of multidimensional impacts of pesticide in fish, environment and human, the scope of the present study is to assess the concentrations of organochlorine pesticide residues; DDT and its metabolites $4,4^{\circ}$-DDT, $2,4^{\circ}$-DDT, DDD and DDE, were investigated in different fish and prawn species commonly available in the flood plains at the Sonargaon upazila of Narayanganj district during rainy-season.

\section{MATERIAL AND METHODS}

Study area and sampling: Fish and prawn samples were collected from the flood plains of Sonargaon upazila of Narayanganj district. The samples were collected from the local fishes men just after caught by net on the bank of the 
flood plains nearby the Meghna river of Sonargaon upazila. Seven fish samples (Jatpunti, Kachki, Tengra, Shing, Chewa, Meni and Bele) and two prawn samples (Gurachingri and Goldachingri) were collected during rainy season (June-September) 2014. Different varieties of fish species (Puntius. sophore, Coricasoborna, Mystu svittatus, Heteropnuestes fossilis, Pseudapocryptus elongatus, Nandusnandus, Glossogobius giuris, unidentified Gurachingri and Macrobrachium rosenbergii) of different trophic levels were collected. The collected fish and prawn samples kept in jip-locked plastic bag with label in chill-box then transported to the laboratory. In the laboratory, at first the fish samples were identified by using the morphological characteristics, following Fishbase (2014), Rahman (2005) and Shafi and Guddus (1982). After identification and taken measurements of biological parameters (Length, width and weight), the samples were stored in freezer at $-20^{\circ} \mathrm{C}$ until extraction carried out.

Chemicals, Reagents, Solvents and Standard: The certified standards; 2,4 DDT, 4,4 $4^{\prime}$-DDT, 4,4 -DDE and 4,4 -DDD (99\% purity) were purchased from Dr. Ehrenstorfer, Germany. Analytical grade anhydrous magnesium sulfate ( $\left.\mathrm{MgSO}_{4}\right)$, sodium sulfate $\left(\mathrm{Na}_{2} \mathrm{SO}_{4}\right)$ was purchased from Scharlau, Spain. Analytical grade solvent such as hexane $\left(\mathrm{C}_{6} \mathrm{H}_{14}\right)$ and acetone $\left(\mathrm{CH}_{3}\right)_{2} \mathrm{CO}$ were purchased from Sigma Aldrich. Sulfuric acid $\left(\mathrm{H}_{2} \mathrm{SO}_{4}\right)(98 \%)$ and sodium chloride $(\mathrm{NaCl})$ were purchase from Merck, Germany.

Extraction and cleaned-up of fish samples: Before extraction, the samples were kept out from the freezer and let them thaw. Then the scales, fins, viscera, gills were removed and washed with clean water. In case of small fish, whole body was grinded to paste and in case of large fishes, the head was separated from body then weighed each part and grinded to paste with the help of the blender. Grinded fish sample lipid (10 g) extracted by QuEChERS (Quick, Easy, Cheap, Effective, Rugged and Safe) method (Mastoaska and Matrices 2006). The extract was cleaned with sulphuric acid $\left(\mathrm{H}_{2} \mathrm{SO}_{4}\right)$ treatment (Akerblom 1995). For each sample, three replicates were extracted and cleaned-up.The cleaned extracts wereanalyzed by GC-ECD.

Gas chromatographic analysis: A Gas Chromatograph (GC-2010 Shimadzu) coupled with Electron Capture Detector, (GC-ECD) (GC-2010 Shimadzu) was used for analysis of DDT and its metabolites from the cleaned extract. Separations were performed on HP-5 quartz capillary column (30 m long $\times 250$ $\mu \mathrm{m}$ i.d.; $0.25 \mu \mathrm{m}$ film thicknesses), nitrogen was used as carrier (column flow $1.92 \mathrm{~mL} / \mathrm{min}$.) as well as make up gas. The injector and detector temperatures were set at 220 and $290^{\circ} \mathrm{C}$, respectively. All injections were made in split-less/ split mode and injection volume was $1 \mu \mathrm{l}$. The oven temperature was 
programmed as: initial temperatureof $120^{\circ} \mathrm{C}$ hold for $1 \mathrm{~min}$; increased at $20^{\circ} \mathrm{C}$ $\mathrm{min}^{-1}$ to $280^{\circ} \mathrm{C}$; hold for $4 \mathrm{~min}$. Identifications of the organochlorine compounds analyte samples were done by comparing retention time of corresponding certified standard samples and quantification by using external calibration curves of the corresponding reference standard.

LOD, LOQ and Recovery Experiment: Primary standard solutions (500 $\mu \mathrm{g} / \mathrm{l}) \mathrm{of}$ 2,4-DDT, 4,4-DDT, 4,4-DDE and 4,4-DDD were prepared in n-hexane in calibrated $100 \mathrm{~mL}$ volumetric flask. These primary standard solutions were diluted to the middle (100 $\mu \mathrm{g} / \mathrm{l})$ and working standard solutions $(10 \mu \mathrm{g} / \mathrm{l})$, respectively. The working standard solution was serially diluted and the diluted solutions were injected in GC-ECD, LOD (3 times higher than noise), LOQ (3 times higher than LOD) were found out and calibration curves were made (Fig. 1).

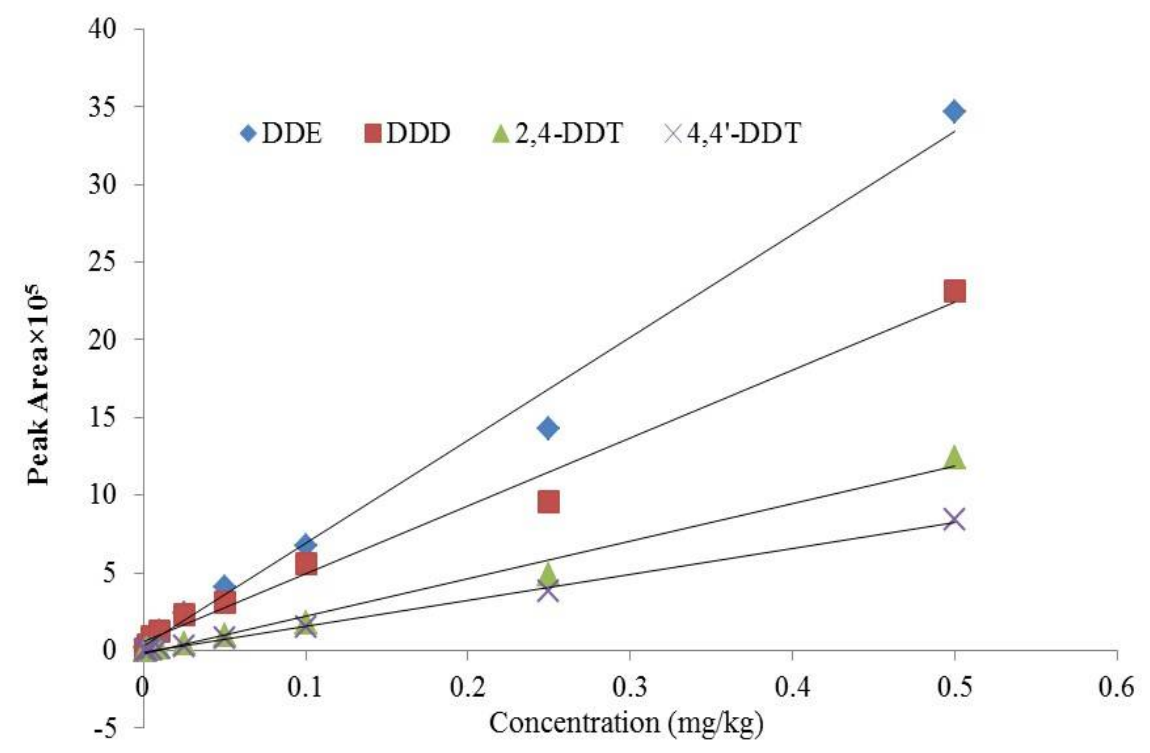

Fig. 1 Calibration curves of standard DDTs solutions.

Residual amount of DDT and its metabolites residues determination were done within the Linearity range (0.025-1,600 $\mu \mathrm{g} / \mathrm{l}$ ) with an $\mathrm{r}^{2}$ (regression coefficient) value were in the range of 0.9840 - 0.9960 of the corresponding standards. Three replicate studies were done for each samples and standard deviation were calculated. The LOD and LOQ for all DDT standards were found to be 0.0625 ngg $^{-1}$ and 0.2063 ngg- $^{-1}$, respectively.

For recovery experiment control fish sample (Cultured Rui fish) was spiked separately with known amount of certified four standards at 3 different concentration levels $(0.05,0.10,0.20 \mu \mathrm{g} / \mathrm{mL}$ or $\mathrm{mg} / \mathrm{kg})$, extraction and cleaned 
up were done following similar procedure as described above and made final volume $1.0 \mathrm{~mL}$. The recovery of the each analyte was calculated according to the following formula:

$$
R=\frac{A_{m} \times C_{s t}}{A_{s t} \times C_{m}} \times \frac{100}{M_{s t}}
$$

where $R$ is the recovery (\%), $A_{m}$ is the peak area of the analyte in the matrix, $A_{s t}$ is the peak area of the analyte in the standard, $C_{m}$ is the concentration of the analyte in the matrix, $C_{s t}$ is the concentration of the analyte in the standard, and $M_{s t}$ is the spiking level (mg kg-1). The percentage recoveries for fish samples were found to be $88.67-92.55 \%, 101.32$ - 113.83\%, $76.25-104.89 \%$ and 70.10 90.78\% for DDE, DDD, 2, 4-DDT, and 4, 4-DDT, respectively.

\section{RESULTS AND DISCUSSION}

Lipid content of fishes: After extraction, total fat contents were determined by gravimetrically. The lipid contents of head, body part and whole body of nine fish and prawn species are shown in Table 1. The lipid contents of the head of different fish and prawn species ranged from $0.50 \pm 0.06 \%$ in Bele to $4.86 \pm$ $0.24 \%$ in Jatpunti (Puntiussophore) and of the body from $0.09 \pm 0.01 \%$ in Goldachingri ( $M$. rosenbergii)to $2.35 \pm 0.17 \%$ in Jatpunti ( $P$. sophore). While the lipid of the whole body of nine fish and prawn species ranged from $0.32 \%$ in Bele (G. giuris) to $2.99 \%$ in Jatpunti (P. sophore). Considering the amount of lipid in whole body, the chronology is Bele (G. giuris) < Shing $(H$. fossilis) < Gurachingri (unidentified) < Kachki $(C$. soborna $)<$ Chewa $(P$. elongatus $)<$ Goldachingri $(M$. rosenbergii) < Tengra $(M$. vittatus) < Meni $(N$. nandus $)<$ Jatpunti $(P$. sophore). The lipid contents of head portion of all fishes were found to be higher than that of the body portion except Sing fish. Similarly Mola, Punti and Sharpunti contained higher lipid value in head portion than body (Mustafa et al. 2015).

DDT and its metabolites: The average concentrations of DDE, DDD, 2,4 DDT, 4,4 DDT and total DDTs ( 2 DDTs)residues in the fishes and prawn species are presented in the Table 2. The total DDTs contents of the head of different fish and prawn species ranged from $7.53 \pm 0.50 \mathrm{ng} / \mathrm{g}$ in Jatpunti $(P$. sophore) to $39.20 \pm 3.76 \mathrm{ng} / \mathrm{g}$ in Bele (G. giuris) and of the body from $7.55 \pm 0.50$ $\mathrm{ng} / \mathrm{g}$ in Jatpunti (P. sophore) to $41.93 \pm 3.63 \mathrm{ng} / \mathrm{g}$ in Chewa (P. elongatus). While the total DDTs of the whole body of nine fish and prawn species ranged from $4.56 \mathrm{ng} / \mathrm{g}$ in Gurachingri (unidentified) to $37.15 \mathrm{ng} / \mathrm{g}$ in Chewa ( $P$. elongatus). Considering the amount of lipid in whole body, the chronology is Gurachingri (unidentified) < Kachki (C. soborna) < Jatpunti (P. sophore) < Shing $(H$. fossilis) < 
Bele (G. giuris) < Goldachingri (M. rosenbergii) < Tengra (M. vittatus) < Meni $(N$. nandus) < Chewa (P. elongatus). The total DDTs contents of head portion were found to be higher than that of the body portion in Jatpunti (P. sophore), Tengra (M. vittatus) and Bele (G. giuris) while in the Shing (H. fossilis), Chewa ( $P$. elongatus), Meni ( $N$. nandus) and Goldachingri (M. rosenbergii) the values were higher in the body than that of the head. It could be attributed that DDT is lipophilic (ATSDR), so higher DDT content could be accumulated in the head of Jatpunti, Tengra and Bele and in the body of Shing which contained higher lipid value than other body part.

Table 1. Lipid content (\%) of fish and prawn samples from the flood plain of Sonargaon upazila during rainy-season of $2014(n=3)$

\begin{tabular}{lllll}
\hline Local name & Scientific name & Body part & Lipid g\% & $\begin{array}{l}\text { Lipid g\% } \\
\text { (Whole body) }\end{array}$ \\
\hline JatPunti & Puntiussophore & Body & $2.35 \pm 0.17$ & 2.99 \\
& & Head & $4.86 \pm 0.24$ & \\
Kachki & Coricasoborna & Whole body & $1.01 \pm 0.15$ & 1.01 \\
Tengra & Mystusvittatus & Body & $1.02 \pm 0.05$ & 1.78 \\
& & Head & $2.27 \pm 0.13$ & \\
Shing & Heteropnuestesfossilis & Body & $1.09 \pm 0.03$ & 0.99 \\
& & Head & $0.84 \pm 0.12$ & \\
Chewa & Pseudapocryptuselongatus & Body & $0.40 \pm 0.10$ & 1.09 \\
& & Head & $3.50 \pm 0.38$ & \\
Meni & Nandusnandus & Body & $2.02 \pm 0.05$ & 2.54 \\
& & Head & $3.39 \pm 0.28$ & \\
Bele & Glossogobiusgiuris & Body & $0.21 \pm 0.04$ & 0.32 \\
& & Head & $0.51 \pm 0.06$ & \\
Gurachingri & Unidentified & Whole body & $0.92 \pm 0.19$ & 0.92 \\
Goldachingri & Macrobrachiumrogenbergii & Body & $0.09 \pm 0.01$ & 1.69 \\
& & Head & $3.28 \pm 0.16$ & \\
\hline
\end{tabular}

Trophic position and lipid content of aquatic organisms are reliable predictors of OCP concentrations in aquatic ecosystem (Kidd et al. 2001, Crosly et al. 1998). The present analysis showed that Gurachingri (Unidentified), Kachki (C. soborna), and Shing (H. fossilis) fish contained low amount of lipid contents. Gurachingri are omnivorous and because of their juvenile stage may be related to the lower DDT accumulation. Kachki fish mainly feed on phytoplankton and zooplankton while Shing feed on insects and plant materials due to their omnivorous nature (Shafi and Guddus 1982). As these three fishes occupy lower trophic levels in the food chain (may be just after the herbivore) and together with their low lipid contents may be related to their low DDTs residues. 


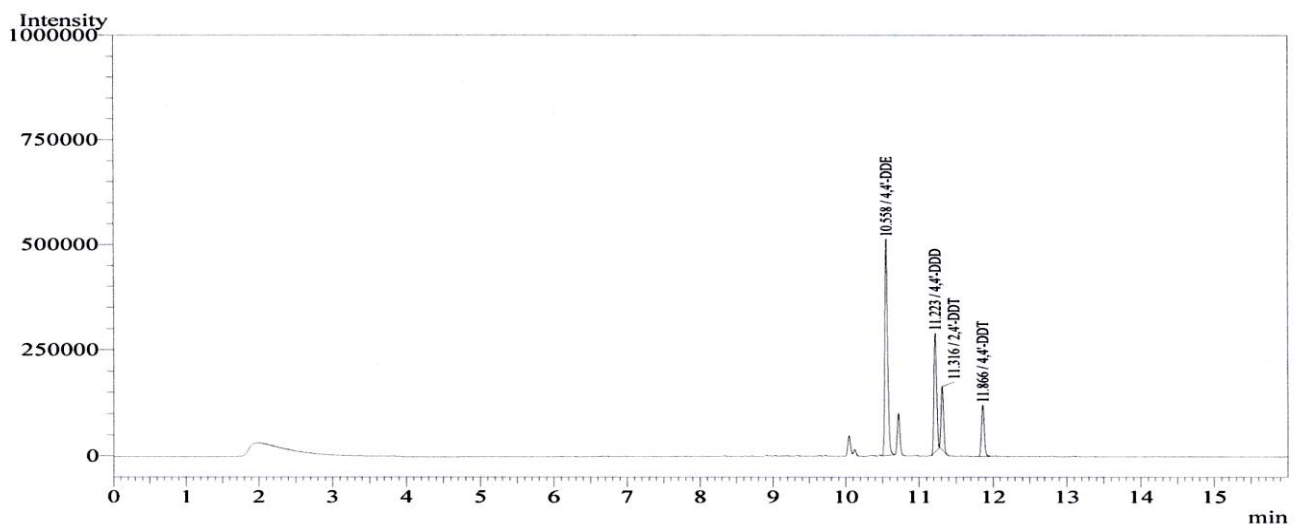

Fig. 2. GC chromatogram of standards.

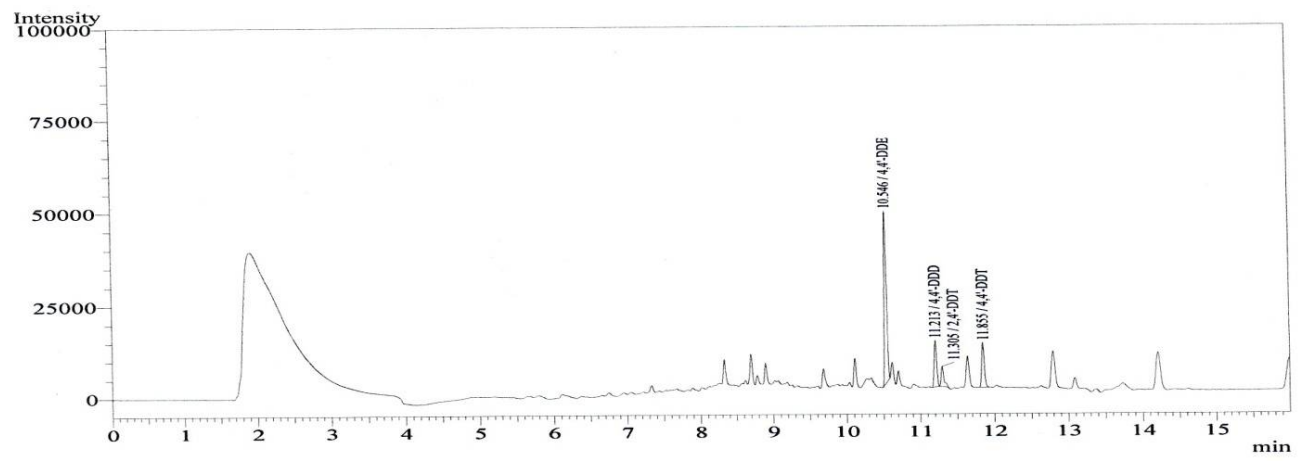

Fig. 3. GC chromatogram of a sample.

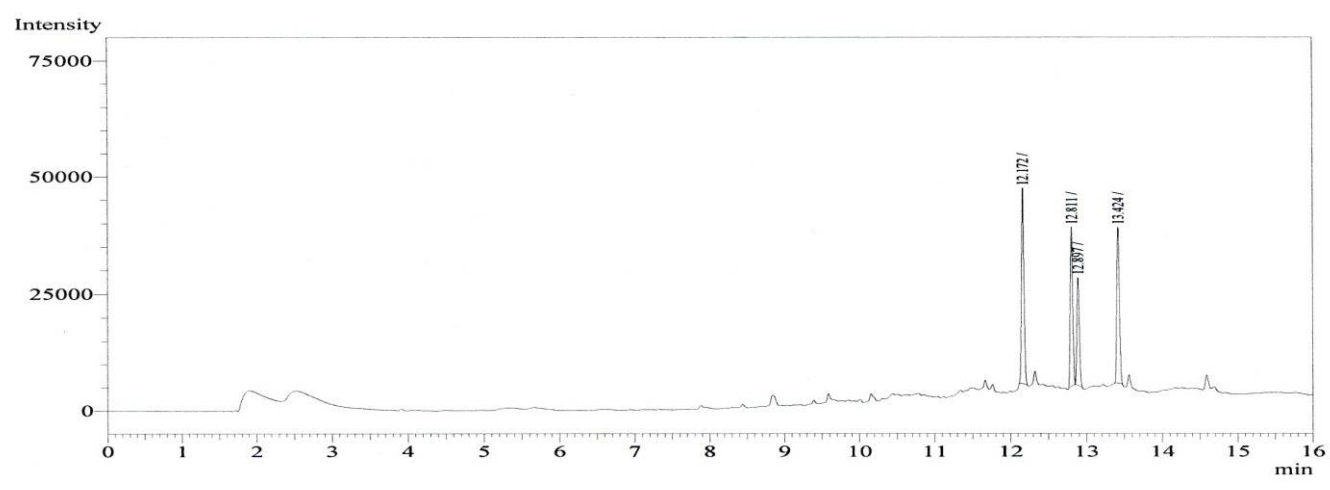

Fig. 4. GC chromatogram of a recovery sample.

Jatpunti (P. sophore) mainly feed on algae, plant material and small amount insects due to omnivorous nature (Fishbase 2014, Shafi and Guddus 1982) while contained higher lipid contents may be responsible for comparatively lower DDTs accumulation but higher than Kachki and Gurachingri. 


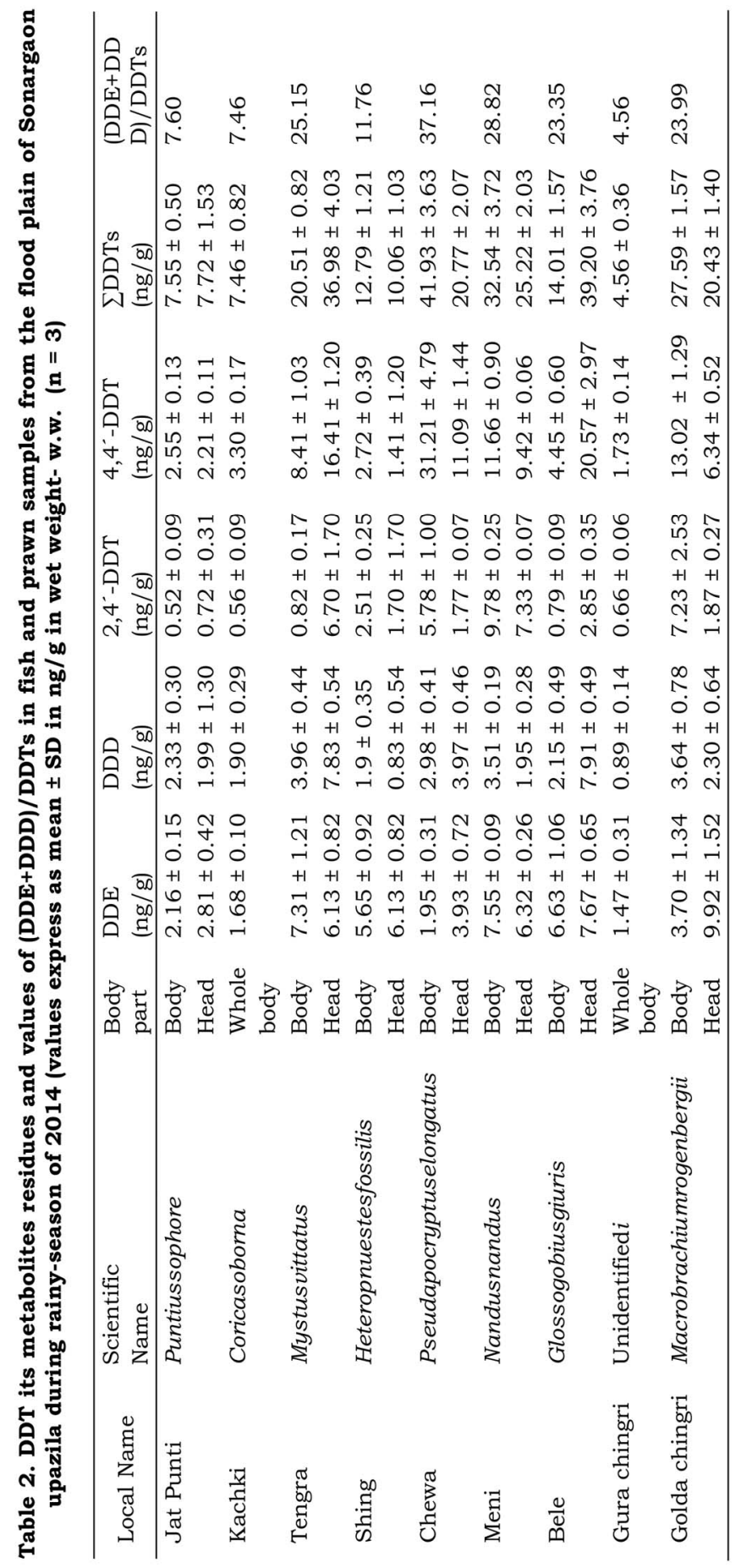


Bele (G. giuris) is carnivore and cannibalistic in nature. Food items mainly consist of fish, crustaceans, insects, zooplankton and on the other hand considerable time of the year a recognizable proportion of food composed of juvenile of Bele (Hossain et al. 2016b). Because of its very low lipid content may be related to medium DDT accumulation. Goldachingri ( $M$. rosenbergii) also contained medium amount of DDTs residue may be related to their low lipid content. Moreover Goldachingri is an omnivorous species that mainly feed on plankton, Diatoms, Copepods and small Crustaceans. Similar result was reported by Nahar et al. (2008).

Tengra (M. vittatus) are omnivorous fishes feed mainly on small fishes, insects, mollusks and little amount of algae and plant material (Chaklader et al. 2014, Gupta and Banerjee 2016) together with higher amount of lipid contents may be the cause of containing higher DDTs residues.

Meni ( $N$. nadus) is a bottom and column feeder and feed mainly on small fish, prawn, fish fry, chironomid and insect larvae and predominantly carnivorous fish (Mustafa et al. 1980). Chewa (P. elongatus) depends on shrimps and non-shrimp crustaceans mainly include copepods, crab larvae, mysids and amphipods predominantly as it is carnivore (Rahman et al. 2016).

Persistent lipophilic organic compounds bioaccumulate and biomagnify with increasing trophic levels (ATSDR, 2002 and Connell, 1995). Similar trends of DDT accumulation to higher levels in fishes of higher trophic levels observed, reaching levels thousand times higher than in water and organisms at lower trophic level. Therefore, the higher amount of DDTs residues in Chewa, Meni in the present study are in accordance with their higher trophic position in food chain. Similarly the significant higher concentration of DDTs were also found in carnivorous species African catfish (Clarias gariepinus) from the lake Koka, Ethoipia (Deribe et al. 2011).

Therefore, it could not be said that all fishes of higher lipid contents contained higher residues level or all fishes of higher trophic levels contained higher residue levels. Both the lipid contents and (or) the trophic position were the predictor of concentrations of organochlorine residues, also reported in the fishes from subarctic lakes in Yukon Terrritoy (Kidd et al. 1998, 2001).

Time of DDT exposure: The ratio of (DDE+DDD)/DDT is a helpful tool in rivaling the significance of the degradation of DDT and to evaluate the current or past use of DDT in the region (Kidd et al. 1998). The ratio higher than 0.5 indicates past input of DDT while lower indicates recent input of DDT. In the present study, 66.66\% samples having value of (DDE+DDD)/DDT, lower than 0.5 ratios that shown in Table 2 . These result indicated that the presence of new DDT inputs in the environments of Sonargaon area. Fresh inputs of DDTs were 
also reported in India (Chourasiya et al. 2014) Uganda (Sseburgere et. al. 2009), South China (Hao et al. 2014) and in Brazil (Rissato et al. 2007) etc.

\section{CONCLUSION}

The mean concentration of DDT residues detected in fish samples from the flood plain ofSonargaon region were below maximum residue limit (MRL) of DDTs in fish $(5000 \mathrm{ng} / \mathrm{g}$ Codex Alimentarius, 1993) indicating that the fishes were safe to consume but continuous consumption of such fishes may cause a threat to human health as a result of biomagnifications. As DDT is a long persistent and bioaccumulative substance in the environment, intake of significant amount of this slow poison with our diet is a matter of health concern. Whilewe could not avoid the fish as they provide essential nutrients like omega-3 fatty acid, minerals, calcium and vitamins so we should select fish in our diet considering the factors that regulate the accumulation of DDTs residues (DDTs residues varies to food habit, age, lipid value, digestion rate, habitat of fishes and also seasons) and by proper selection, we could get essential nutrients with safe from Persistent Organic Pollutants (POPs) consumption also.

Acknowledgements: The authors are grateful to International Science Programme (ISP), University of Uppsala, Uppsala, Sweden, Bangabandhu fellowship, Ministry of Science and Technology, Bangladesh and Higher Equation Quality Enhancement Project (HEQEP) for financial support.

\section{LITERATURE CITED}

ADEYEMI, D., UKOKPO, G., ANYAKORA, C. and UNYIMADU, J.P. 2008. Organochlorine pesticide residues in food samples from Lagos markets, Nigeria. Am. J. Environ. Sci. 4(6): 649-653.

AKERBLOM, M. 1995. Environmental Monitoring of Pesticide Residues-Guidelines for the SADC Region. Department of Environmental Assessment, Swedish University of Agricultural Sciences, Uppsala, Sweden.

ATSDR, 2002. Toxicological Profile for DDT, DDE, DDD. US Department of Health and Human Services, Public Health Service, Atlanta, GA. http://www.atsdr.cdc.gov/toxprofiles/tp35-p.pdf (Adopted-2013).

CHAKLADER, M.R., NAHAR, A., SIDDIK, M.A.B. and SHARKER, R. 2014. Feeding Habits and Diet Composition of Asian Catfish Mystus vittatus (Bloch, 1794) in Shallow Water of an Impacted Coastal Habitat. World J. Fish. Marine Sci. 6(6): 551-556.

CHOURASIYA, S., KHILLARE, P.S. and JYETHI, D.S. 2014. Health risk assessment of organochlorine pesticide exposure through dietary intake of vegetables grown in the periurbansites of Delhi, India. Environ. Sci. Pollut. Res. DOI 10.1007/s11356-014-3791-x (Adopted-2013).

CODEX ALIMENTARIUS COMMISSION. 1993. Pesticides Residues in Food, Joint FAC/WHO Food Standards Programme, 23. 
CONNELL, D.W. 1995. Prediction of bioconcentration and related lethal and sublethal effects with aquatic organisms. Mar. Pollut Bull. 31: 201-205.

CROSLY, R.W., DONALD, D.B. and BLOCK, H.O. 1998. Trends and seasonality in a- and ghexachlorocyclohexane in western Canadian surface waters (1975-1994). Environ. Pollut. 103: 277-285.

DERIBE, E., ROSSELAND, B.O., BORGSTROM, R., SALBU, B., GEBREMARIAM, Z. and DADEBO, E. 2011. Bioaccumulation of persistent organic pollutants (POPs) in fish species from Lake Koka, Ethiopia: the influence of lipid content and trophic position. Sci. Total Environ. 410: 136-145.

EDWARDS, C. A . 1987. The environmental impact of pesticides. Parasites 86: 309-329.

FISHBASE. 2014 A global information system on fishes. http://www.fishbase.org/ (Adopted-2014).

GUPTA, S. and BANERJEE, S. 2016. Eutropiichthysvacha (Hamilton, 1822), a threatened fish of Indian subcontinent. J. Fisher. 4(2): 397-400.

HAO, Q., SUN, Y.Z., XU, X.R., YAO, Z.W., WANGC, Y.S., ZHANG, Z.W., LUO, X.J. and MAI, B.X. 2014. Occurrence of persistent organic pollutants in marine fish from the Natuna Island, South China Sea. Marine Pollut. Bull. 85: 274-279.

HOSSAIN, M.A., SHOEB, M. and NAHAR, N. 2016a. DDT and Its Metabolites in Fresh Water Fish Samples. J. Food Sci. Engin. 6: 344-350.

HOSSAIN, M.S., ROY, A, and RAHMAN, M. L. 2016b. Food and feeding habit of Bele Glossogobiusgiuris (Hamilton and Buchannan, 1822) Collected from Mithamain Haorof Kishoreganj districts, northeastern Bangladesh. Inter. J. Fish. Aquatic Stud. 4(5): 84-88.

KIDD, K.A., BOOTSMA, H.A., HESSLIEIN, R.H. and MUIR, D.C.G. 2001. Biomagnification of DDT through the benthic and pelagic food webs of Lake Malawi, East Africa, importance of trophic level and carbon source. Environ. Sci. Technol. 35: 14-20.

KIDD, K.A., SCHINDLER, D.W., HESSLEIN, R.H. and MUIR, D.C.G. 1998. Effects of trophic position and lipid on organochlorine concentrations in fishes from subarctic lake in the Canadian Arctic. Environ. Pollut. 102: 91-103.

MASTOASKA, K., and MATRICES, M. 2006. Rapid Sample Preparation Method for LC-MS/MSor GCMS Analysis of Acrylamide in Various Food Matrices. J. Agri. Food Chem. 54(19): 7001-8.

MATIN, M., MALEK, M., AMIN, M., RAHMAN, S., KHATOON, J. and RAHMAN, M. 1998. Organochlorine insecticide residues in surface and undergroundwater from different regions of Bangladesh. Agri. Ecosys. Environ. 69: 11-15.

MUSTAFA, G., AHMED, A.T.A. and ISLAM, K.R. 1980. Food, feeding habits and fecundity of freshwater perch, Meni fish. Bangldesh. J. Agri. http://agris.fao.org/arris-search/search. recordID =XB812540 (Adopted-2014)

MUSTAFA, T., NASER, M. N., MURShED, S., FARHANA, Z., AKTER, M. and ALI, L. 2015. Fatty acid composition of three small indigenous fishes of Bangladesh. Bangladesh J. Zool. 43(1): 85-93

NAHAR, N., MAMUN, M.I.R., ZAMIR, R. and. MOSHIUZZAMAN, M. 2008. Analysis of Pesticide Residues in Some Local Fish and Vegetable. Dhaka Univ. J. Sci. 56(2): 1-4.

NDS (Narayangang District Statistics). 2013. Reported by the Bangladesh Bureau of Statistics (BBS), Statistics and Informatics Division (SID), Ministry of Planning, Government for the People's Republic of Bangladesh (Adopted-2014).

RAHMAN, A. K. A. 2005. Freshwater fishes of Bangladesh. $2^{\text {nd }}$ ed. Zoological Society of Bangladesh, Dhaka. pp-143, 152, 270, 276, 220,224, 189, 190, 316, 317, 345,346, 325, 333, 18. 
RAHMAN, M.S., RAHMAN, M.M., PARVEZ1, M.S. and RASHED-UN-NABI, M. 2016. Feeding habit and length-weight relationship of a Mudskipper Apocryptesbato (Hamilton, 1822) from the coast of Chittagong, Bangladesh. J. Bang. Acad. Sci. 40(1): 57-64.

RAHMAN, S. and THAPA, G.B. 1999. Environmental impacts of technological change in Bangladesh agriculture: farmers' perceptions and empirical evidence. Outlook Agri. 28: 233-238.

RISSATO, S., MARIO, S., GALHIANE,VALDECIR, F., XIMENES, A. and CAVAlARI, A. 2007. Organochlorine pesticides and polychlorinated biphenyls in soil and water samples in the Northeastern part of São Paulo State, Brazil. Chemosphere 65(11): 1949-1958.

SHAFI, M. and QUDDUS, M.M.A. 1982. Bangladesher Matshya Shampad (in Bengali). $1^{\text {st }}$ ed. Bangla Academy, Dhaka. pp-2-14.

SSEBUGERE, P., KIREMIRE, B.T., KISHIMBA, M., WANDIGA, S.O., NYANZI, S.A. and WASSWA, J. 2009. DDT and metabolites in fish from Lake Edward, Uganda. Chemosphere. 76: 212-215.

YU, H., BAO, L.J., LIANG, Y. and ZENG, E.Y. 2011. Field validation of anaerobic degradation pathways for dichlorodiphenyltrichloroethane (DDT) and 13 metabolites in marine sediment cores from China. Environ. Sci. Technol. 45: 5245-5252.

(Manuscript received on 19 May, 2019; revised on 20 May, 2019) 